\title{
Kajian Hukum Mengenai Tindakan Korps Brigade Mobil Polri Terhadap Pelaku Pelanggaran Protokol Kesehatan Covid-19
}

\section{Legal Study On Actions Of The Polri Mobile Brigade Corporate Against Health Protocol Violations For Covid-19}

\author{
Damai Syukur Waruwu* 1), Ediwarman2) \& Marlina $^{2)}$ \\ 1)Program Studi Magister Ilmu Hukum, Universitas Medan Area, Indonesia \\ 2) Program Studi Magister Ilmu Hukum, Universitas Sumatera Utara, Indonesia \\ Diterima: 15 Juni 2021; Direview: 02 Agustus 2021; Disetujui: 30 September 2021
}

*Coresponding Email: imanuel@gmail.com

\begin{abstract}
Abstrak
Tulisan ini bertujuan untuk mengkaji dan menganalisis aturan hukum yang mengatur tentang pelaku pelanggaran protokol kesehatan covid-19, faktor penyebab terjadinya pelanggaran protokol kesehatan covid-19 di Sumatera Utara, dan kebijakan yang diambil oleh Korps Brigade Mobil Polri terhadap pelaku pelanggaran protokol kesehatan Covid-19. Permasalahannya adalah pandemi Covid-19 menuntut respons Polri sebagai aparat penegak hukum dalam memainkan perannya dalam upaya pengendalian penyakit, edukasi kepada masyarakat, dan penindakan tindak kejahatan yang melihat wabah sebagai kesempatan untuk melakukan berbagai tindak kejahatan. Guna mendekati masalah ini dipergunakan teori sistem hukum. Data-data dikumpulkan melalui pedoman wawancara dan dianalisis secara kualitatif. Kajian ini menyimpulkan bahwa aturan hukum yang mengatur tentang pelaku pelanggaran protokol kesehatan covid-19 diatur dalam peraturan Undang-Undang Nomor 2 Tahun 2002 Tentang Kepolisian Negara Republik Indonesia, Peraturan Pemerintah Nomor 21 Tahun 2020 Tentang Pembatasan Sosial Berskala Besar (PSBB) Dalam Rangka Percepatan Penanganan Corona Virus Disease 2019 (Covid-19), serta peraturan lainnya seperti Surat Telegram Bernomor ST/3220/XI/KES.7./2020, Peraturan Menteri Kesehatan, Instruksi Menteri Dalam Negeri. Faktor yang mendorong terjadinya pelanggaran protokol kesehatan adalah faktor intern terdiri dari faktor ekonomi dan kurangnya keperdulian masyarakat. Faktor ekstern terdiri dari kebiasaan masyarakat, ketidakpercayaan masyarakat kepada pemerintah, adanya kebijakan new normal. Kebijakan brimob yang diambil adalah kebijakan penal dan non penal.
\end{abstract}

Kata Kunci: Kajian Hukum; Tindakan; Korps Brimob; Pelaku Pelanggaran; Protokol Kesehatan; Covid-19

\begin{abstract}
This paper aims to examine and analyze the legal rules governing the perpetrators of the Covid-19 health protocol violation, the factors causing the Covid-19 health protocol violation in North Sumatra, and the policies taken by the Police Mobile Brigade Corps against the Covid-19 health protocol violations. . The problem is that the Covid-19 pandemic demands a response from the Police as law enforcement officers in playing their role in disease control efforts, educating the public, and taking action against crimes that see the outbreak as an opportunity to commit various crimes. To approach this problem, the theory of the legal system is used. The data were collected through interview guidelines and analyzed qualitatively. This study concludes that the legal rules governing the perpetrators of violating the Covid-19 health protocol are regulated in Law Number 2 of 2002 concerning the Indonesian National Police, Government Regulation Number 21 of 2020 concerning Large-Scale Social Restrictions (PSBB) in the Context of Accelerating Handling Corona Virus Disease 2019 (Covid-19), as well as other regulations such as Telegram Letter Numbered ST/3220/XI/KES.7./2020, Regulation of the Minister of Health, Instruction of the Minister of Home Affairs. Factors that encourage violations of health protocols are internal factors consisting of economic factors and lack of public concern. External factors consist of people's habits, people's distrust of the government, the existence of new normal policies. Brimob policies taken are penal and non-penal policies.
\end{abstract}

Keywords: Legal Studies; Action; Mobile Brigade Corps; Offenders; Health Protocol; Covid-19.

How to Cite: Waruwu, D.S., Ediwarman, E., \& Marlina, M. (2021). Kajian Hukum Mengenai Tindakan Korps Brigade Mobil Polri Terhadap Pelaku Pelanggaran Protokol Kesehatan Covid-19. Journal of Education, Humaniora and Social Sciences (JEHSS). 4 (2): 1090-1095. 


\section{PENDAHULUAN}

Sejak awal tahun 2020 Indonesia dan seluruh dunia dikejutkan oleh merebaknya penyakit menular yang disebabkan oleh covid-19. Covid-19 yang pada awalnya berasal dari China tersebut telah menyebabkan gangguan kesehatan bagi masyarakat dan menjadi pembunuh nomor satu dengan jumlah kematian yang relatif besar. Di samping mengganggu kesehatan, penyebaran covid-19 juga telah mengganggu seluruh sendi-sendi kehidupan masyarakat dan roda pemerintahan negara (Akhbar, Dkk, 2019).

Penyebaran covid-19 juga telah menyebabkan terkurasnya keuangan negara sebagai upaya pengendalian penyebaran penyakit dan sebagai upaya merawat pasien covid-19. Pemerintah telah mengalihkan anggaran dari pos-pos pembangunan ke pos kesehatan agar perawatan pasien covid dapat dilakukan dengan baik. Pemerintah juga telah mendirikan rumah sakit yang secara khusus diperuntukkan bagi pasien covid-19 dengan pengeluaran dana yang relatif besar (Busyro, 2019).

Sebagai wujud dari upaya pemerintah dalam mengendalikan penyebaran covid-19, maka pemerintah telah membuat berbagai kebijakan yang harus dilakukan atau dipatuhi dalam kehidupan masyarakat sehari-hari yang disebut dengan protokol kesehatan. Dalam protokol kesehatan tersebut pemerintah telah mengeluarkan berbagai peraturan untuk membatasi gerak masyarakat agar dapat menyendalikan penyebaran covid-19. Salah satu peraturan tesebut adalah Permenkes No. 9 tahun 2020 tentang Pedoman Pembatasan Berskala Besar Dalam Rangka Dalam peraturan tersebut dinyatakan bahwa percepatan Penanganan Corona Virus Disease 2019 (Covid19). Pembatasan Sosial Berskala Besar adalah pembatasankegiatan tertentu penduduk dalam suatu wilayah yang diduga terinfeksi Corona Virus Disease 2019 (COVID-19) sedemikian rupa untuk mencegah kemungkinan penyebaran Corona Virus Disease 2019 (COVID-I9).

Pandemi Covid-19 menuntut respons Polri sebagai aparat penegak hukum dalam memainkan perannya dalam upaya pengendalian penyakit, edukasi kepada masyarakat, dan penindakan tindak kejahatan yang melihat wabah sebagai kesempatan untuk melakukan berbagai tindak kejahatan. Kepolisian diberi tugas dan wewenang untuk melakukan pengawasan dan melakukan tindakan terhadap pelanggaran protokol kesehatan (Ginting \& Muazzul, 2018).

Menurut Pasal 2 Undang-Undang No. 2 Tahun 2002 tentang Polri, dinyatakan bahwa "Fungsi kepolisian adalah salah satu fungsi pemerintahan negara di bidang pemeliharaan keamanan dan ketertiban masyarakat, penegakan hukum, perlindungan, pengayoman, dan pelayanan kepada masyarakat".

Kepolisian diberi tugas dan wewenang untuk melakukan pengawasan dan melakukan tindakan terhadap pelanggaran protokol kesehatan. Tetapi dari pengamatan penulis bahwa kepolisian belum melakukan tindakan tegas kepada setiap pelaku pelanggaran protokol kesehatan, karena hingga saat ini sebagian besar tindakan kepolisian masih sebatas himbauan dan terkesan terlalu persuatif terhadap pelaku pelanggaran. Tindakan kepolisian yang demikian tentu kurang mendorong kepatuhan masyarakat terhadap kebijakan protokol kesehatan sehingga berpotensi semakin meningkatkan penyebaran penyakit covid-19.

Berdasarkan permasalahan yang tersebut diatas, yang menjadi tujuan dari penelitiann ini adalah untuk mengkaji dan menganalisis aturan hukum yang mengatur tentang pelaku, faktor penyebab dan kebijakan yang diambil oleh Korps Brigade Mobil Polri terhadap pelaku pelanggaran protokol kesehatan Covid-19.

\section{METODE PENELITIAN}

Spesifikasi penelitian yang dipergunakan dalam penulisan tesis ini adalah metode penelitian yuridis normatif bersifat deskriptif analisis, yaitu penelitian yang dilakukan dengan cara meneliti bahan pustaka (data sekunder) atau penelitian hukum perpustakaan. Penelitian hukum normatif merupakan suatu prosedur penelitian ilmiah untuk menemukan kebenaran berdasarkan logika keilmuan hukum dari sisi normatifnya. Penelitian hukum normatif atau doktriner yang diajukan dalam kajian ini adalah penelitian terhadap asas-asas hukum dan sinkronisasi hokum (Ginting, Dkk, 2019). 
Penelitian ini menggunakan bahan yang diperoleh dari hasil penelitian kepustakaan, dari penelitian kepustakaan dikumpulkan data sekunder yang meliputi bahan hukum primer, bahan hukum sekunder dan bahan hukum tersier. Penelitian normatif, data yang diperlukan adalah data sekunder. Data sekunder tersebut mempunyai ruang lingkup yang sangat luas, sehingga meliputi surat-surat pribadi, buku-buku harian, sampai pada dokumen-dokumen resmi yang dikeluarkan oleh pemertintah (Hadi, 2010).

Alat pengumpulan data menggunakan studi dokumen dan pedoman wawancara. Data yang diperoleh melalui penelitian kepustakaan maupun data yang diperoleh melalui penelitian lapangan akan dianalisis secara kualitatif. Analisis kualitatif yaitu analisis data dengan mengelompokkan dan menyelidiki data yang diperoleh dari penelitian lapangan menurut kualitas kebenarannya, kemudian dihubungkan dengan teori-teori yang diperoleh dari studi kepustakaan, sehingga diperoleh jawaban dari permasalahan yang diajukan.

\section{HASIL DAN PEMBAHASAN}

\section{Aturan hukum yang mengatur tentang pelaku pelanggaran protokol kesehatan covid-19}

Dalam Pasal 13 Undang-Undang No. 2 Tahun 2002 tentang Kepolisian Negara RI, disebutkan bahwa tugas pokok Polri, adalah memelihara keamanan dan ketertiban masyarakat, menegakkan hukum, memberikan perlindungan, pengayoman, dan pelayanan kepada masyarakat (Halawa, Dkk, 2020).

Berkaitan dengan hal tersebut maka dalam masa pandemi Covid-19, tugas pokok Polri tersebut dipertegas lagi dengan dikeluarkannya beberapa Telegram dari Kapolri diantaranya sebagai berikut: Surat Telegram Nomor ST/1098/IV/HUK.7.1/2020 tentang penanganan kejahatan potensial selama pembatasan sosial berskala besar (PSBB) yang didalamnya mengatur mengenai pedoman kepada personel kepolisian dalam melakukan tindakan hokum; Surat Telegram Nomor: ST/1099/IV/HUK.7.1/2020 yang mengatur tentang penanganan kejahatan dalam tugas ketersediaan bahan pokok dan distribusi; Surat Telegram Nomor: ST/1100/IV/HUK.7.1/2020 yang mengatur mengenai penanganan kejahatan di ruang siber; Surat Telegram Nomor ST/1101/IV/HUK.7.1/2020 yang mengatur mengenai penanganan kejahatan potensial dalam masa penerapan PSBB; Surat Telegram Nomor ST/1102/IV/HUK.7.1/2020 yang mengatur mengenai penanganan tenaga kerja Indonesia (TKI) yang baru tiba dari negara terjangkit Covid-19 (Hasmayni, 2016).

Berdasarkan Peraturan Pemerintah Nomor 21 Tahun 2020 Pasal 1, dijelaskan bahwa Pembatasan Sosial Berskala Besar merupakan pembatasan kegiatan tertentu dalam suatu wilayah yang diduga terinfeksi Coronavirus Disease 2019 (COVID-19).

Pembatasan Sosial Berskala Besar (PSBB) dilaksanakan selama masa inkubasi terpanjang dan dapat diperpanjang jika masih terdapat bukti penyebaran. Permenkes itu menjelaskan, sekolah dan tempat kerja diliburkan kecuali kantor atau instansi strategis yang memberikan pelayanan terkait: pertahanan dan keamanan; ketertiban umum; kebutuhan pangan; bahan bakar minyak dan gas; pelayanan kesehatan; perekonomian; keuangan; komunikasi; industry; ekspor dan impor; distribusi logistik, dan kebutuhan dasar lainnya (Muhammad, 2014).

Salah satu perintah dalam surat Surat Telegram Bernomor ST/3220/XI/KES.7. / 2020 Untuk Pelaku Pelanggaran Protokol Kesehatan adalah agar jajaran kepolisian menegakkan hukum tanpa pandang bulu terhadap pelanggar protokol kesehatan yang mengganggu keamanan dan ketertiban masyarakat. "Apabila dalam penegakan perda/peraturan kepala daerah tentang penerapan protokol kesehatan Covid-19, ditemukan adanya upaya penolakan, ketidakpatuhan atau upaya lain yang menimbulkan keresahan masyarakat dan mengganggu stabilitas kamtibmas, maka lakukan upaya penegakan hukum secara tegas terhadap siapapun (Siallagan \& Siregar, 2017).

\section{Faktor penyebab terjadinya pelanggaran protokol kesehatan covid-19 di Sumatera Utara}

Faktor ekonomi adalah faktor internal manusia dan keluarnya yang merupakan kemampuan suatu keluarga dalam memenuhi kebutuhan hidupnya sehari-hari. Kemampuan masyarakat dalam memenuhi kebutuhan hidup sehari-hari sangat mempengaruhi tingkat kepatuhannya terhadap protokol kesehatan (Silalahi, 2018). Keluarga atau masyarakat yang kurang mampu cenderung 1.96\% http://mahesainstitute.web.id/ojs2/index.php/jehss 1092

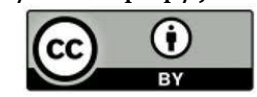


kurang patuh dan sering melakukan pelanggaran karena mereka berkepentingan untuk memenuhi kebutuhan hidup sehari-hari yang justru lebih tidak dapat diabaikan dalam menjalani kehidupan keluarga.

Faktor kurangnyanya kesadaran masyarakat. Kesadaran masyakat untuk mematuhi protokol kesehatan masih tergolong sangat rendah. Masyarakat mengetahui adanya penyebaran pandemic saat ini serta dampak yang telah ditimbulkannya tetapi mereka tidak perduli, terutama kalangan anak muda yang merasa dirinya kuat dan kebal. Faktor kurangnya kesadaran masyarakat menjadi faktor penyebab terjadinya pelanggaran protokol. Masyarakat yang kurang sadar cenderung tidak perduli dengan himbauan pemerintah, padahal sebenarnya mereka telah mengetahui adanya peraturan protokol serta mengetahui bahwa penyebaran covid-19 sudah semakin meluas (Silalahi, Dkk, 2019).

Faktor kebiasaan masyarakat. Yang dimaksud dengan kebiasaan masyarakat disini adalah kebiasaan sosial khususnya kebiasaan berkumpul dalam melaksanakan acara tertentu, seperti acara pesta adat ataupun acara lainnya yang melibtkan masyarakat banyak. Faktor kebiasaan mendorong masyarakat melakukan pelanggaran terhadap protokol kesehatan, khususnya kebiasaan menyelenggarakan pesta adat dalam skala besar yang melibatkan ratusan bahkan ribuan orang.

Faktor ketidakpercayaan masyarakat kepada pemerintah. Masyarakat saat ini dalam kondisi kurang percaya terhadap pemerintah sehubungan dengan covid-19. Banyak masyarakat tidak percaya sehingga mereka tidak patuh dan terus melakukan pelanggaran terhadap protokol kesehatan. Sedang terjadi krisis kepercayaan masyarakat kepada pemerintah dalam hal informasi dan penangan pandemic covid-19.

Faktor kebijakan new normal (normal baru). Kebijakan new normal (normal baru) banyak disalahtafsirkan oleh masyarakat dalam pelaksanaannya. Kebijakan normal baru justru menyebabkan masyarakat kembali pada kebiasaan hidup sebagaimana tidak ada pandemic covid19. Sebagian besar masyarakat kurang memahami maksud dari kehidupan normal baru, dan menggapnya sebagai sebagai kebebasan untuk keluar rumah walaupun tanpa adanya pelindung diri dan berada di keramaian (Soekanto, 2012;2013).

\section{Kebijakan yang diambil oleh Korps Brigade Mobil Polri terhadap Pelaku Pelanggaran Protokol Kesehatan Covid-19}

Kebijakan penal berupa tindakan brimob dalam mendukung pencegahan penyebaran covid19 masih dapat dikatakan kurang tegas, karena masih hanya sebatas mengeluarkan himbauan dengan sanksi yang tergolong sangat ringan. Hingga saat ini sebagian besar tindakan brimob masih sebatas himbauan dan terkesan terlalu persuatif terhadap pelaku pelanggaran. Tindakan yang diberikan kepada pelaku pelanggaran protokol kesehatan pun masih terbatas pada sanksi ringan, seperti sanksi kerja sosial dan tindakan fisik seperti push up di tempat. Tindakan lain yang dilakukan oleh brimob atas pelanggaran protokol kesehatan adalah membubarkan kerumunan massa, yang yang berkerumun di tempat-tempat umum maupun yang berkerumun di acara pesta, tanpa disertai dengan proses atau tindak lebih lanjut sebagaimana seharusnya penanganan tindak pidana.

Memberi Himbauan. Himbauan merupakan tindakan persuatif yang dilakukan oleh brimob terhadap pelaku pelanggaran. Pendekatan persuasif yang dilakukan oleh brimob kepada pelaku pelanggaran adalah dengan menghimbau agar pelaku sadar untuk mematuhi protokol kesehatan untuk melindungi diri dan melindungi orang lain dari penyebaran covid-19. Terhadap mereka yang tidak menggunakan masker dihimbau agar jika keluar rumah selalu menggunakan masker, sedangkan kepada mereka yang menggunakan masker tidak tepat diingatkan agar masker benarbenar digunakan sesuai dengan keperluannya. Pendekatan utama berupa himbauan yang demikian dilakukan karena pada dasarnya pandemi ini bukanlah kesalahan masyarakat umum.

Pemberian Sanksi Ditempat. Korps Brigade Mobil Polri dapat memberi tindakan kepada pelaku pelanggaran protokol kesehatan berupa pemberian sanksi. Sanksi yang diberikan dapat berupa sanksi administrasi seperti denda, sanksi kerja sosial, serta sanksi tindakan fisik ditempat. Tindakan brimob dalam pemberian sanksi kepada pelaku pelanggaran masih terbatas pada 触http://mahesainstitute.web.id/ojs2/index.php/jehss (v) mahesainstitut@gmail.com 
pemberian sanksi kerja sosial, administrasi, dan juga sanksi berupa tindakan fisik. Sanksi kerja sosial diterapkan jika pelaku tidak bersedia atau tidak sanggup membayar denda sanksi administrasi sebesar yang ditetapkan.

Kebijakan non penal berupa Harapan terhadap segera berakhirnya kondisi pandemi covid19 saat tentu menjadi sesuatu kondisi yang paling mendesak untuk dicapai mengingat telah banyak korban yang terjadi sebagai akibat penyebaran pandemi covid-19, yang mulai dirasakan di Indonesia sejak bulan Maret hingga saat ini. Korban yang dimaksud tidak hanya korban material, tetapi juga termasuk korban jiwa yang jumlah sangat besar, baik di kalangan masyarakat umum maupun di kalangan paramedis.

Penerapan Protokol Kesehatan Oleh Brimob. Kepatuhan terhadap protokol kesehatan harus dimulai dari diri sendiri, yaitu anggota brimob yang berperan penting dalam penegakan hukum. Brimob harus menerapkan protokol kesehatan sesuai dengan aturan yang berlaku disemua tempat, baik di kantor, dilapangan maupun ditengah-tengah masyarakat. Dengan menerapkan protokol kesehatan oleh anggota brimob maka diharapkan akan menjadi contoh bagi masyarakat mengenai bagaimana seharusnya berperilaku sesuai dengan aturan protokol yang ada. Tetapi fakta yang sering ditemukan adalah bahwa masih terdapat banyak anggota brimob yang justru melakukan pelanggaran terhadap protokol kesehatan, yaitu dengan cara mengabaikan penggunaan masker di tempat umum ataupun dikantor.

Sosialisasi Yang Gencar Kepada Masyarakat. Brimob harus secara aktif melakukan sosialisasi mengenai pentingnya penerapan protokol kesehatan. Brimob perlu aktif terjun secara langsung ke lingkungan masyarakat untuk melakukan sosialisasi peraturan protokol kesehatan, yaitu dengan memberitahukan dampak-dampak buruk yang ditimbulkan oleh covid-19 kepada masyarakat, serta memberitahukan sanksi-sanksi yang akan diterima oleh pelaku jika tidak mematuhi atau melakukan pelanggaran protokol kesehatan (Tambunan, Dkk, 2019).

Aktif Melakukan Pengawasan. Pengawasan merupakan tindakan preventif yang diperlukan untuk mencegah terjadinya pelanggaran hukum, karena dengan adanya pengawasan terhadap aktivitas masyarakat maka diharapkan masyarakat menjadi lebih hati-hati dalam bertindak, termasuk juga dalam bertindak melakukan pelanggaran protokol kesehatan.

Penegakan Hukum Yang Tegas. Penegakan hukum menjadi faktor penting untuk mendorong kepatuhan masyarakat terhadap peraturan yang berlaku. Jika penegakan hukum dilakukan terlalu longgar maka dapat dipastikan bahwa masyarakat juga akan kurang serius dalam mematuhi hukum yang berlaku

\section{SIMPULAN}

Aturan hukum yang mengatur tentang pelaku pelanggaran protokol kesehatan covid-19 diatur dalam peraturan Undang-Undang Nomor 2 Tahun 2002 Tentang Kepolisian Negara Republik Indonesia, Peraturan Pemerintah Nomor 21 Tahun 2020 Tentang Pembatasan Sosial Berskala Besar (PSBB) Dalam Rangka Percepatan Penanganan Corona Virus Disease 2019 (Covid19), Surat Telegram Bernomor ST/3220/XI/KES.7./2020 Untuk Pelaku Pelanggaran Protokol Kesehatan. Faktor yang mendorong terjadinya pelanggaran protokol kesehatan adalah faktor intern terdiri dari faktor ekonomi dan kurangnya keperdulian masyarakat. Faktor ekstern terdiri dari kebiasaan masyarakat, ketidakpercayaan masyarakat kepada pemerintah, adanya kebijakan new normal. Kebijakan brimob yang diambil adalah kebijakan penal, yaitu memberi himbauan, menerapkan sanksi tindakan di tempat, serta tindakan mencegah kerumunan massa. Kebijakan non penal, yaitu penerapan protokol kesehatan oleh Brimob, sosialisasi yang gencar kepada masyarakat, aktif melakukan pengawasan, penegakan hukum yang tegas. Disarankan satuan brimop perlu menerapkan protokol kesehatan secara lebih baik agar dapat menjadi contoh bagi masyarakat umum. Satuan brimop perlu lebih gencar melakukan sosialisasi kepada masyarakat luas tentang peraturan protokol kesehatan serta sanksi hukum bagi pelanggaran protokol kesehatan. Satuan brimop perlu melakukan pengawasan terhadap aktivitas masyarakat dengan menempatkan personilnya pada fasilitas umum khususnya tempat yang rawan terjadinya pelanggaran protokol kesehatan. Satuan brimop perlu melakukan penegakan hukum yang tegas kepada setiap pelaku pelanggaran, tidak terbatas hanya tindakan di lapangan tetapi juga harus

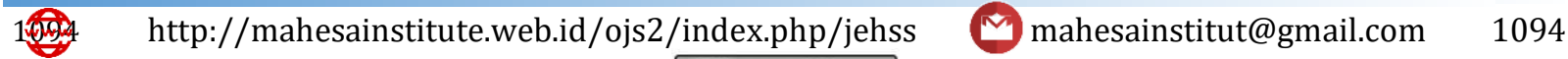

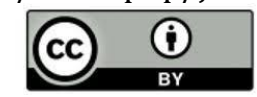


diproses sesuai dengan hukum dengan menangkap dan menyerahkan tersangka kepada penyidik kepolisian.

\section{DAFTAR PUSTAKA}

Akhbar, A.T.F, Maswandi \& Kartika A. (2019). Perlindungan Hukum Bagi Anak Dalam Tindak Pidana Pencurian Dengan Kekerasan Yang Mengakibatkan Matinya Korban (Studi Putusan No. 37/Pid.SusAnak/2017/PN. Mdn). JUNCTO, 1(2) 2019: 183-192,

Busyro, M. (2019). Tinjauan Kriminologis Terhadap Preman yang Melakukan Kejahatan (Studi Kasus Polsek Batangtoru). DOKTRINA: JOURNAL OF LAW, 2(2), 99-116. doi:https://doi.org/10.31289/doktrina.v2i2.2614

Ginting, H. \& Muazzul. (2018). Peranan Kepolisian dalam Penerapan Restorative Justice terhadap Pelaku Tindak Pidana Pengeroyokan yang Dilakukan oleh Anak dan Orang Dewasa, Jurnal Ilmiah Penegakan Hukum, 5 (2): 32-40.

Ginting, S.Y, Lubis, A.A, \& Zulyadi, R. (2019). Penerapan Sanksi Hukum Tindak Pidana Pemerkosaan Yang Dilakukan Oleh Anak (Studi Putusan No. 65/Pid.Sus-Anak/2017/PN. Mdn). JUNCTO, 1(2) 2019: 166173 ,

Hadi, S, (2010), Metodologi Research, Yayasan penerbit Fakultas Psikologi UGM, Yogyakarta.

Halawa, M., Munawair, Z., \& Hidayani, S. (2020). Penerapan Hukum Terhadap Tindak Pidana Pembunuhan Dengan Sengaja Merampas Nyawa Orang Lain (Studi Kasus Nomor Putusan 616/Pid.B/2015/PN. Lbp). JUNCTO, 2(1) 2020: 9-15

Hasmayni, B, (2016), Perilaku Agresif pada Anggota Geng Motor Ditinjau dari Tingkat Usia dan Suku di Kota Medan, Jurnal Pendidikan Ilmu-Ilmu Sosial, 8(2).

https://bebas.kompas.id/baca/riset/2020/04/18/rangkaian-peristiwa-pertamacovid-19, diakses pada tanggal 2 Februari 2021.

https://www.who.int/indonesia/news/novel-coronavirus/qa-for-public, diakses pada tanggal 2 Februari 2021.

Muhammad, A, (2014), Metode Penelitian Hukum, Citra Aditya Bakti, Bandung.

Siallangan, A.F, \& Siregar, T. (2017). Peranan Kantor Pengawasan Dan Pelayanan Bea Dan Cukai Belawan Dalam Penanggulangan Penyelundupan Satwa Dilindungi Jurnal Ilmiah Penegakan Hukum, 4 (1) 2017: 1-7

Silalahi, D.H. (2018). Penanggulangan Tindak Pidana Penyalahgunaan Narkotika di SAT RES Narkoba Polres Tebing Tinggi, Jurnal Ilmiah Penegakan Hukum5, (2): 60- 67.

Silalahi, S.D, Munawir, Z \& Syaputra, M.Y.A, (2019). Perlindungan Hukum Bagi Pekerja Kontrak Yang Mengalami Pemutusan Hubungan Kerja Pada Masa Kontrak (Studi Kasus Putusan Nomor: 82/Pdt.SusPhi/2016/PN. Mdn). JUNCTO, 1(2) 2019: 174-182,

Sitorus, J., Zulyadi, R. \& Trisna, W. (2020). Perlindungan Hukum Terhadap Korban Tindak Pidana Pencurian Ditinjau Dari Kajian Victimlogi (Studi Putusan No : 20/Pid.B/2017/PN. Mdn). JUNCTO, 2(1) 2020: 41-50

Soekanto, S, (2012), Sosiologi Suatu Pengantar, Rajawali Pers, Jakarta.

Soekanto, S, (2013), Pengantar Penelitian Hukum, Universitas Indonesia Press, Jakarta.

Tambunan, R, Suhatrizal \& Siregar, T. (2019). Penegakan Hukum Terhadap Tindak Pidana Kepabean Penyeludupan Pakaian Bekas (Putusan No. 237/Pid.B/2016/PN. Tjb). JUNCTO, 1(2) 2019: 158-165,

World Health Organization, 2020, Archived: WHO Timeline - COVID-19, Diperoleh dari https://www.who.int/news-room/detail/27-01-2020-who-timeline---COVID-19.

Perundang-undangan:

Kitab Undang-Undang Hukum Pidana (KUHAP)

Undang-Undang Nomor 2 Tahun 2002 Tentang Kepolisian Negara Republik Indonesia.

Kitab Undang-Undang Hukum Pidana (KUHP)

Undang-Undang Nomor 2 Tahun 2002 Tentang Kepolisian Negara Republik Indonesia.

Peraturan Pemerintah Nomor 21 Tahun 2020 Tentang Pembatasan Sosial Berskala Besar (PSBB)

Surat Telegram Bernomor ST/3220/XI/KES.7. /2020. 